\title{
Public Administration 4.0 : Theoretical Exploration of Disruptive Governance Paradigm
}

\author{
Ahmad Syakrani Bunasim \\ Department of Social and Political Science, Public Administration Science Study Program, Lambung Magkurat \\ University, Banjarmasin, South Kalimantan (email: syakrani@ulm.ac.id or rony_sandra25@yahoo.com)
}

\begin{abstract}
For a long time, public sector was trapped in a false belief; a myth that it did not need to change, that it did not need to be strong, wiser, agile, dynamic, and adaptive to an everchanging environment as it became an inevitable factor for corporations, who had to maintain their competitive advantage in order to always to be more excellent than other corporations. This paper will trace that in the era of Fourth Industrial Revolution, the public sector has to earnestly get out of this trap and need to inject new DNA; not only entrepreneurship DNA, but also disruptive governance DNA that inducts on innovative disruption, agility, and dynamic governance so that it will not only carry out the routinized governance responsibilities, but it can also be present in the middle of the public with strong, wiser, agile, adaptive, and humane presence. This paper concludes with an offer of a model of disruptive governance that is the core of Public Administration 4.0.
\end{abstract}

\section{Keywords:}

public sector; the fourth industrial revolution; agility and dynamic; disruptive governance DNA; the public administration 4.0

\section{A False belief}

In the trias politica concept, the executive institution is only one of three branchs of power but it is better known as the main state institution involved in governmental affairs to realize the nation-state visions through the formulation and implementation of public policy in order to help and serve public or citizens (Willoughby, 1927). These affairs denote the narrowest sense of all governmental affairs that he called as administrative branch of government. They are implemented by the executive body with its public sector institutions that formed public administration. ${ }^{1}$ In the United States (USA) or Indonesia for example it was called as Obama Administration or Jokowi Administration. The association of such

${ }^{1}$ In this paper, this concept will be more widely used as a science and government practice by adding the word praxis. 
work with executive body is even more prominent in a country that implements a presidential system of government and which is experiencing an executive-heavy.

By definition, the public sector institutions -- or more commonly known as public bureaucracy -- are the public institutions governing of governmental affairs under the government sponsorship [funds and employees]. Therefore, they have a formal obligation to be accoutable for their resposibiltiy to the government (Lane, 2000; Rainey, 2019).

The problem is, for long ago all of us believed that these institutions would never lose and bankrupt. In the era of New Public Management Movement (NPM Movement) this belief is understood as a false belief. It was only a myth that makes public generally, bureaucrats and government feel totally immersed in the myth for a long time. This myth is very detrimental to the public as whole. There are many indicators indicate them. For example is the foreign debt.

Almost all countries in the world have foreign debt, not except rich countries such as the US and Saudi Arabia, including Indonesia. I don't need presenting these data, but obviously the number is always going up.

The question is, how many social development programs for public services and for increasing the public prosperity should be delayed due to its installment payments? How long do public as whole have to delay for getting more quality public services because the installments suck up most of the state budget?

We haven't calculated any other indicators. For example environmental degradation. How much natural resources are left to support development programs through modernization or industrialization?

Its early warnings were well narrated in Our Common Future (1987). But we have not been moved to truly healthy ways of thinking in designing the development policies and strategies through the utilization of natural resources. Senge et al. (2008) insinuases that we - even in terms of science and technology mastery more advanced -- are not as smart and wise as traditoinal people in maintaining ecological balance. We turn out to put our greedy first rather than fulfillment our needs. Gandhi said that the earth and its entire richs are enough to meet our needs, but not for our greedy. 
Another one, corruption. If we refer to the global corruption perceptions index, the phenomena is actually global. The difference is only at its level of the scandalousness and law enforcement.

This practice clearly is detrimental to anyone both materially and morally. The question is the same: how many hospitals, basic health centers, educational institutions, and economic development programs can be realized by corrupted funds to improve our human development index? How many people and public officials have imitated that practice both in the regional and village levels of government, because they are starting to see that the practice is not wrong both legally and morally (cooruption banality both legally and morally)?

Just another one, the low absorption of development budget. It denotes the weakness and sluggishness of the public sector spending funds already provided by the state. What if this sector for example were asked for earning money as envisioned by Osborne and Gaebler (1993), not from rent-seeking? But to be sure, the absorption can be used as an indicator of the loss of the government and the people as whole.

There's sometihing more visible. Caiden (1991) wrote an article on What is Really Maladministration? He discussed more than 150 burea-pathologies that he thought that they are are universal. Drucker (1980) also wrote about The Six Deadly Sins In Public Administration. ${ }^{2}$ He calculated that over $40 \%$ of the country's money doesn't know where and what the people really feel due to the six deadly sins? Is this not detrimental to anyone? Why we still do held this false belief?

Generally, all countries and governments everywhere are now under stress. Kettl (2013) wrote The System Under Stres. This stress was not just a new condition faced by the government and the public sectors, but this new condition comes with the past ones. They made the pressure stronger and more detrimental. In this case, it was not just the government that is under stress, but the people as whole, who are then manifested in movement of no longer trust in the state or government.

In the UK, it was manifested in a politically hostile attitude towards the state and government. Through political entry point of slimming the state, the movement wanted to

\footnotetext{
${ }^{2}$ This the six deadly sins consist of: [1] lofty (unspecified) objectives without clear targets; [2] doing several things at once without establishing and sticking to priorities; [3] believing that fat is beautiful; [4] being dogmatic, not experimental; [5] failing to learn from experience and feedback; [6] and assuming immortality and being unwilling to abandon pointless programmes.
} 
slim the fat deposits on the state and government. Their roles and functions were reduced as much as possible for sliming down. The slimmed roles and functions are then handed over to the private sector.

This entry point is guided by the pluralist state ideology. The main belief of this ideology is "there-is-a-state-within-a-state." The others state are private sectors which are always ready to perform the slimmed functions, including public service functions provision. The privatization or commercialization is the best choise. TINA -- there is no alternatives -turned into the ideological jargon of this movement.

The US choosen another entry point: strengthening the state. Rather than were slimmed, fats deposit in the state or government are instead transformed into muscles to produce new DNA as discoursed by Osborne and Gaebler (1993) in Reinventing Government. This entry point was built on trust in the government and the state, and on the the belief that civilized society is only possible when the state or government is strong and healthy.

\section{The Ketll's Stateless Public Administration Model}

The burden of the state and government is getting heavier. They now are under stress. This condition is result from the implementation of Administrative State Model designed by Waldo. Kettl utilizes the Ostrom's criticism of this model to design a new model: The Stateless Administration Model. He elaborates more seriously on Stillman's offer (Perry and Christensen, 2015) after responding positively to Ostrom's criticism.

Ketll's view of the new model needs to be discussed here as it will be used as an entry point for the development of a newer model, The Public Administration 4.0, albeit with a somewhat different theorical basis. At least for three reasons why it needs to be discussed.

First, Kettl ideas could be put into a counter-thought stream of The Waldo's Administrative State, but not in calculation of constitutional imperatives. Instead it is very pragmatical choices. Second, Ketll belongs to a new generation of experts or scholars of public administration who give their own thoughts in the development of the theories of public administration, which may also be included in the lines of The NPM Movement.

Third, as part of the movement, he certainly hold the ideology of the pluralist state; an ideology that believed in "there-is-a-state-within-a-state." The ideology, as mention above, historically turned later into as theorical basis for New Public Management in the UK and in the US better known as the Reiventing Government. 
There are some pragmatical calculations that Ketll put forward to reject Waldo's Administrative State Model. These calculations boil down to the ever-changing environment, which has implications for the demands to transform governance that apply today. His criticism of Waldo's model focuses on the "all-embracing" characteristic of public administration.

Kettl said that Waldo defined public administration as a series of integral and crosscommunity collective activities, as a larger-enterprises, which accommodate as large a range of social, economic and political activities as possible. It is vast and will always be directly proportional to the population and its dynamics.

"Public administration is integral to collective action across-societies. Public administration is indeed a large-scale social activity; it is larger enterprises."

According to Kettl, it has the limit, but at the same time has no limit. This was criticized by Ketll. This governance model will be harmful if it is maintained, because the model will be slow in meeting the demand of changes, especially if the they are escalated by public expectation explosion. Rapid changes must be answered by eliminating the monopoly of government power [another term of limited "all-encompassing"].

Along with rapid change, he identified three other major forces for the inevitability of transformation from the old model to the new one: [1] evolutionary transformation,[2] the erosion of the boundaries of public administration with other areas of life, and [3] challenges to accountability and public law. Some of the interesting calculations he presents are worth looking at, for example:

1. Fiscal pressures and the collapse of US financial markets in the fall of 2008, as well as the collapse of several investment banks.

2. The decline of public trust in government.

3. The increasing public cynicism towards the government due to pressure on the system of government is slow to be overcome.

These three factors escalated into a major evolutionary transformation of governance; not only in the US, but also in other countries in various forms of transformation, such as:

1. Privatization and contracting out.

2. Implementation of customer-driven, citizen-centered government.

3. Implementation of open government. 
4. Implementation of public performance management.

5. Fiscal reforms.

6. Professionalism deepening and human capital development.

7. Implementation of networked governance.

According to Kettl, it was these transformations of governance that formed the new face of $21^{\text {st }}$ century government, which he called as the Public Administration for Twenty-First Century and the Beyond. This is a new model according to him and other supporters of the NPM Movement that is suitable for governing for the collective actions of the $21^{\text {st }}$ century and the beyond. ${ }^{3}$

Kettl's new model is interesting, but we should keep in mind its ideological background -- the pluralist state ideology. For the sake of efficiency and effectiveness (value for money) in the implementation of public policy, the model sets the 3ES (economy, efficiency and effectiveness) as its main values. The greatest risk of applying this ideology is the silent takeover by other state [in the pluralist state ideology] through large multinational corporations for capitalist developed countries as Hertz and Korten have warned us loudly.

The model offered in this paper only agrees with Kettl's conception about transformation of governance, but it must be encapsulated it by different theoretical strands: disruptive governance. It must include at least three important elements: [1] in line with Osborne and Gaebler's model, the offer should be built on the foundation of trust in the state and government that Randers (2012) forecasted for the next forty years; ${ }^{4}$ [2] such engagement also insisted of implementing state activism; ${ }^{5}$ and [3] besides agile and dynamic, the Public Administration for Twenty-First Century and the Beyond requires another new DNA: disruptive innovation, innovative disruption or creative destruction.

\footnotetext{
${ }^{3}$ See Kettl (2008) in The Next Government of The United States; and Bell (2017) in Your Next Government?

${ }^{4}$ According to him, in the face of great tendencies in the future, the state must be more engaged and the government must be stronger, wiser and agile (tregginas).

${ }^{5}$ State activism, as stated by Siong and Chen (2007) about Singapore, was an imperative factor that the state was always reach the highest rank in terms of dynamic governance performance
} 


\section{Disruptive Governance}

According to Scharmer and Kaeufer (2013), this era was disruption era; an era of great disruption. In this era, besides we will be experiencing many crises, difficulties, and great challenges, we also will find almost everything is experiencing upside down.

However, the concept of disruption here is not as understood by Scharmer and Kaeufer (2013) or even by Fukuyama (1999), but it is closer to the sense of the great shifting (Kasali, 2017, 2018) and by disruptive innovation (Christensen, 2008; Schwab, 2018). The era here is characterized by an abundance of creative destruction. It be the core force of deep change that had an unimaginable huge impact before on all aspects of human life. It then went very fast, unprompted, and impromptu, as he diffused with some technological breakthroughs. Then, it be disruptive technology (Schwab, 2018). That's the Fourth Industrial Revolution.

What is the impact of the change on the public administration as science?

This is my core idea which I will discuss in this paper by tracing a next paradigm of public administration. I name it The Public Administration 4.0. It will studies and examines the new DNA of disruptive governance. The DNA will have strategic implications for adapatation of the paradigm content and theories of this science to the new trends.

This model is based on future trends known as MegaChanges 2052 especially those are predicted by Canton (2006), Randers (2012) and Schwab (2018). Randers's global forecasts total approximately 36 trends. ${ }^{6}$ Two of which are:

1. Stronger government.

2. A stronger role for wise government.

The most important thing to be underlined in these prediction is that state should get more involved and government should also be stronger, wiser and agile in governing all aspects of public life. The heart of these tendencies are how the state and its government should formulate and implement policies that make those changes can strengthen themselves and

6It is divided into five main trend groups: [1] population and consumption to 2052; [2] energy and $\mathrm{CO}_{2}$ to 2052; [3] In 2014, the government food and footprint to 2052; [4] the nonmaterial future to 2052; and[5] the nonmaterial future to 2052 
increase the public prosperity? It's imperative trend that undoubtedly be the need for that new paradigm. ${ }^{7}$

Schwab's statement below justifies the urgency of the new paradigm. He said that the Fourth Industrial Revolution (RI 4.0) was a continuation of previous revolutions. But its scale, depth, speed and scope are vastly different. Its change power to all aspects of life is also great. It created a non-incremental and revolutionary impact and made historical discontinuity.

"Of the many diverse and fascinating challenges, we face today, the most intense and important is how to understand and shape the new technology revolution, which entails nothing less than a transformation of humankind. We are at the beginning of a revolution that is fundamentally changing the way we live, work, and relate to one another. In its scale, scope and complexity, what I consider to be the fourth industrial revolution is unlike anything humankind has experienced before."

"We have yet to grasp fully the speed and breadth of this new revolution. Consider the unlimited possibilities of having billions of people connected by mobile devices, giving rise to unprecedented processing power, storage capabilities and knowledge access. Or think about the staggering confluence of emerging technology breakthroughs, covering wide-ranging fields such as artificial intelligence (AI), robotics, the internet of things (IoT), autonomous vehicles, 3D printing, nanotechnology, biotechnology, materials science, energy storage and quantum computing, to name a few."

The urgency of new paradigm in the public administration is not a dream. It is very urgent need. Let's look at his opinion again,

"We are witnessing profound shifts across all industries, marked by the emergence of new business models, the disruption of incumbents and the reshaping of production, consumption, transportation and delivery systems. On the societal front, a paradigm shift is underway in how we work and communicate, as well as how we express, inform and entertain ourselves. Equally, governments and institutions are being reshaped, as are systems of education, healthcare and transportation, among many

${ }^{7}$ The author wrote two three-piece books discussing Towards a Next Paradigm of Public Administration. The first, titled Tracing the Public Administration 4.0, has been published. The second, titled Tracing a Next Paradigm of Public Administration, is still in print, while the third, titled Toward a Next Paradigm of Public Administration, is still in the process of writing. 
others. New ways of using technology to change behavior and our systems of production and consumption also offer the potential for supporting the regeneration and preservation of natural environments, rather than creating hidden costs in the form of externalities. The changes are historic in terms of their size, speed and scope." Some important things we can rewrite from the above opinion, which can be used as a justification for the anticipation of the new paradigm, as follows:

1. Profound shifts across all industries, marked by the emergence of new business models, the disruption of incumbents and the reshaping of production, consumption, transportation and delivery systems.

The concept of industry means two aspects: industrial sector and all affairs. Regardless of which one to refers, it has serious implications for state and government.

In the context of first meaning, state or government should have the ability to anticipate the birth of new industries which based on RI 4.0 tenhnological breakthrough with policy and or regulation that give life to them. These policies and regulations should be are able to facilitate the development of start-up business that are much more technological, competitive, and cheap. In this case, there will be many incumbent resistances who fear falling out. They seek government protection to maintain their businesses existence and viability that are starting to be threatened by the start-ups.

These policies and regulations should not also turn off the start-ups creativity because government want to protect incumbents, or vice versa. They are generally slow in implementing RI 4.0 technological breakthrough. They will collapsed and went bankrupt because of these changes. Workers in the incumbent businesses or industries will lose their jobs.

On the other hand, the government must have the ability to revitalize state-own industrial sectors, such as those under BUMNs or BUMDs. Industrial sectors that have difficulty in adapting to the industrial revolution must be revitalized in order not to add the burden of the state and government.

Including in this context are state universities and collages. Which of them should be cyberized to produce appropriate new research findings, new technologies, and 
human resources? Which of them must be revitalized in order for its excellence to be improved or even which to merge to optimize its roles?

Public service procurement systems (health, education, and transportation, communication, and other government services) revitalization in this regard are also important. Can these systems provide institutional support for these changes? Do existing rules or policies now support the systems that will be burdened by future demands? Does the public bureaucracy still be bottlenecks for the acceleration of the service?

The word industry can also means all business or social affairs, which can include the concept of public with its problem. There will be more societal affairs that require different types and forms of government regulation than they are now. There will be public affairs or services that must be digitalized and not digitalized. The application of advanced technology is not the main goal in itself; it is just an instrument. Its final measure is the improvement of people's well-being.

2. On the societal front, a paradigm shift is underway in how we work and communicate, as well as how we express, inform and entertain ourselves.

The integrity of the nation state depends heavily on social resilience at the societal level; not just on the National Armed Forces (TNI) and the State Police.

Social resilience is key. Thus, the RI 4.0 technological breakthroughs in the field of communication and information technologies (ICT) that is deep into daily life has to be an important part in the life of citizens. These should be part of all the links that strengthen the integrity.

The flow of information due to the implementation of ICT will be abundant with a very fast level of sharing. Is it all useful or just a hoax?

We learn from the presidential election how hoax power was able to create strong political segregation and dangerous social conflict? Government should have the ability to manage the flow of information through the policy of improving the ICT literacy without any limiting the use of advances or breakthroughs in RI 4.0 technology.

3. Equally, governments and institutions are being reshaped, as are systems of education, healthcare and transportation, among many others. 
The public sectors should be reshaped. We can say proudly who says elephants can't dance (Gerstner, Jr., 2002). As an organization, they can be as agile as the Exponential Organizational (ExO) model. As a public services provider, they can be more efficient, entrepreneurial, creative, innovative, cheap, and accessible. As a regulator, they can be more adaptive and anticipatory. As an economic actor, they can be increasingly more disruptive. As a political stabilizer, they must be stronger, wiser and fairer. And as a guardian of the state constitution and sovereignty, they can be increasingly more authoritative, and so on. Reshaped or public sector reform is a focus of study of public administration as a science. Of course the reformation does not just include the institution dimension, but the culture, mindset and the processes dimensions in it.

Schwab, Canton, Randers, Christensen, and other thoughts formed a momentum for the birth of disruptive governance paradigm. They have great relevance to the science of public administration, especially in some ways. For example, if we try to associate disruptive innovation with why nations fail theory, Christensen's disruptive innovation and Acemoglu and Robinson's theory are very relevant. According to Christensen, disruptive innovation does not happen in a vacuum context.

In Chapter of So Close and Yet So Different, Acemoglu and Robinson said that North and South Korea were so closed, but still so different. If the answer is disruptive innovation (Christensen), then the next problem is, doesn't this innovation only fit with a certain type of regime: inclusive economic and political institutions (Acemoglu and Robinson). Their answers complemented Christensen's answer.

Christensen warned that innovation can't always boost social justice. For one country or a specific segment of the population, it can improve the quality of life, but not for others. Innovation itself only thrives in an inclusive economic and political institutions (Acemoglu and Robinson). In fact, they said, these regimes are an important factor in creating sustainable prosperity. But their potential to create social inequality in a country is also very high, because they occur in an economic system that relies on market mechanisms and competition, that also have potential for widening socioeconomic inequality. Thus, Randers's answer as described above -- state engagement and stronger government - should be the solution.

The regime model offered by Acemoglu and Robinson is only closely related to innovation that Christensen says that it is a factor in increasing the ability of a nation to get 
out of poverty, while Randers's offer -- state engagement and stronger government -- is an important factor preventing potential socioeconomic inequality due to innovation and inclusive economic and political institutions regimes.

All of the above theories - Christensen, Acemoglu and Robinson and Randers theories - are at heart of the science of public administration. Inclusive economic and political institutions must be selectively sterilized from the market mechanisms and free markets; the power of innovation as a creator of prosperity must be fortified from its anti-thesis on socioeconomic justice with the public policies that vertically can make opportunities for public bureaucracy to hold unbottlenecking roles for the development that must be competitive and can increase the competitiveness of the nation. Horizontally, they should be able to support the sectors that control the all of the grass-roots' economy.

Randers's thinking has been realized in India in the 2007. Using the tagline of Farming 4.0 , the nation transformed the agricultural sector, especially in the smallholder subsector into digitalized one. McKinsey and Company (2017) reported that for increasing the production, productivity, and income of economic actors of these subsectors, they applied digital innovation.

The report explains that the agricultural sector in India is full of contradictions. The agricultural sector production covers $11 \%$ of all the world's agricultural sector production. However, at the same time, it is precisely describing that population in the sectors were the most malnourished population in the world. The agricultural sector provides jobs opportunity for half the population, especially in smallholders, but government subsidies are widely enjoyed by large-scale plantations. The digital innovation of these subsectors and state engagement can change the image of the culprit. The production, productivity, and welfare of these subsectors increased sharply. Forbes (2014) revealed that there are six digital transformations that can be implemented in the agricultural sector, namely:

1. IoT and sensors in the field.

2. IoT and sensors in equipment.

3. Drones and crop monitoring.

4. Farming and robotics.

5. RFID sensors and tracking.

6. Machine learning and analytics. 
According to Newman (2018), the author of an article in this magazine,

"People in the industry-farmers, food producers-must embrace the digital transformation trends in agriculture. By using technology as a sustainable and scalable resource, we will be able to take agriculture to new heights, keeping farm to fork in our future."

Learning from India's success, it is not impossible to digitize the agricultural sector in Indonesia in the next time. Of course, it has to be done gradually starting from the problem of land reform and the change in peasant work ethic. This requires the presence of state an government in the stronger and wiser mannes as put forward by Randers.

According to the report, there are 25 things that demonstrate the readiness of governments -- stronger state and government involvement -- for the success of the digital transformation of the agricultural sector. That readiness is in all layers of stakeholders; not only farmers, but also politicians who provide political support and a legal framework so that the government and its public bureaucracy can transform the sector digitally.

One of the RI 4.0 technological breakthroughs was the application of e-government. According to Ojo and Millard (2017), in some parts of the earth it marks our entry into the Era of Government 3.0. The technology infrastructure supports and its rapid progress helped Government 3.0 developed increasingly.

They said that public policymakers and academics are already aware of the importance of their presence so that the public sector has a fresh vision of innovating.

“Policymakers and academics largely recognise the need for a fresh vision for public sector innovation and the use of technology in government given the challenging and turbulent contexts in which most public administrations operate. In response, recent studies have sought to better understand the forces that will shape the future evolution of the public administration environment."

In the next time from now, we only have to evaluate its efficiency level (Rodríguez-Bolívar, 2014), its sustainability (Paulin et al., 2017), and degree of the openness of the government (Gascó-Hernández, 2017) after implementing e-gov.

Healthcare services have the most potential to undergo technological and digital transformation. State and government should implement policy and regulation which can accelerate the improvement of the quality of services, health technology, medical personnel 
and health workers immediately based on the RI 4.0 technological breachthrough. Thuemmler and Bai (2017) warns that in the era of Health 4.0, the rapid development of visualization and big data technologies will revolutionize healthcare.

"During the nineteenth and twentieth centuries the art of medicine was advanced, especially with regard to therapeutic interventions. Now the focus has shifted over recent decades, we are able to look deeper and deeper into the micro-cosmos, observing and analyzing molecular structures, such as DNA, and even go beyond this looking at atomic and sub-atomic level, our ability to foresee is growing stronger. While the elders could only treat conditions they could grasp with their hands, digital imaging became the ultimate diagnostic weapon of the twentieth century, making smaller and smaller structural changes recognizable.

It's an incredible development. At first it was only about technological transformation. But now, they creeps into the question of service, namely public services that inevitably required quality and digitized services.

Public Administration and Information Technology now is conducting a global review to respond to the impact of technological developments on public services in healthcare services. Le, Van Le, Tromp, and Nguyen (2018) revealed that the development of virtual reality, augmented reality, artificial intelligence, internet of things, and robotics in the RI 4.0 era is optimized by the field of medicine and healthcare services.

Table 1

Smartphones HealthCare Applications

\begin{tabular}{|c|c|c|}
\hline No & Apps & Description \\
\hline 1. & Finger Print Thermometer & $\begin{array}{l}\text { It used to determine body temperature with the help of } \\
\text { finger print }\end{array}$ \\
\hline 2. & iOximeter & Calculates oxygen intake that is $\mathrm{SpO} 2$ and pulse rate \\
\hline 3. & Calorie Counter & $\begin{array}{l}\text { Keep track of used food intake and his/her weight and } \\
\text { relationship among them }\end{array}$ \\
\hline 4. & Eye Care Plus & Monitors and tests eye vision \\
\hline 5. & Period tracker & Helps to track periods and forecast fertility \\
\hline 6. & Blood Pressure Watch & Tracks, analyses, shares and collects blood pressure data \\
\hline 7. & Cardiomobile & Remotely monitors cardiac rehabilitation on real time basis \\
\hline 8. & On Track Diabetes & $\begin{array}{l}\text { Helps to monitor and track blood glucose for medication to } \\
\text { manage diabetes }\end{array}$ \\
\hline
\end{tabular}




\begin{tabular}{lll}
\hline No & \multicolumn{1}{c}{ Apps } & \multicolumn{1}{c}{ Description } \\
\hline 9. & Noom Walk & $\begin{array}{l}\text { It acts as pedometer to count user's steps in daily routine } \\
\text { work }\end{array}$ \\
10. & Monitoring Hearth Rate & Used for real time hearth rate monitoring and tracking \\
11. & Google Fit & It is used to track cycling, walking and running for the user \\
12. & Asthma Tracker and Log & Used to track asthma for patient
\end{tabular}

Source: Le, dkk. 2018.

"With the current advances in technology innovation, the field of medicine and healthcare is rapidly expanding and, as a result, many different areas of human health diagnostics, treatment and care are emerging. Wireless technology is getting faster and 5G mobile technology allows the Internet of Medical Things (IoMT) to greatly improve patient care and more effectively prevent illness from developing."

But the digitalization of healthcare services was in fact not only about the application of advanced technology alone. Patient empowerment is also a critical dimension. Technology has the potential to ignore the patient's feelings.

"Patient empowerment is facilitated by the wide availability of medical information via the internet and the ability to share reliable medical information, personal experiences with medicines and medical assessments via social media, in social groups established based on shared interests and a desire to support each other. This enables patients to have a voice in their healthcare procedures and exert more control and influence on healthcare worldwide, making it a very powerful technology-enabled medicine and healthcare improvement."

Again, it is warned that we do not discuss only about health technology and its development (e.g. the use of smartphones for some service or healthcare applications), but the impacts and implications for public services in the field of health, as well as the science that must support it, namely the science of public administration.

And again, we must keep mind Kasali's opinion: doctors or physicians as work are irreplaceable and even more important, but how and what they do when treating and serving patients (as jobs) will be affected by the RI 4.0 technological breakthrough as have been studying by Health 4.0 .

Ethical and empathetic dimensions in serving patients was the other side that should not be ignored. Treating and providing services to patients involves two dimensions of human 
activity at once (Habermas, 1971), namely technical and interactional dimensions. Therefore, ethics is a future skill for doctors and other professionals. It implied that there must be moral and ethical awareness in carrying out our profession (Habermas, 2007).

Tapol as the author of Deep Medicine (2019) was a victim of medical treatment that has undergone shallowing in serving the patience. He called the phenomena as shallow medicine. This model ignores the human side in medicine, because it has been technologicalcentric.

Tapol is a doctor; he even was a leading medical expert in the field of artificial intelligence (AI). Citing the opinion of William Osler, the father of modern medicine, he said, “... just listen to your patient; he is telling you the diagnosis."

“Despite whatever impression you might get from my interest in new technology it has always been a dream of mine to galvanize the essential human element of medical practice."

Just listen to your patient. It's very important.

What is more important in this case is to provide quality and empathic services to a group of people who are socially and technologically far behind. They are experiencing the technological gap. They formed a social group that we well known as disadvantaged groups. Development of medical technology are only related to instruments. The men, women, and their interests, needs and aspirations behind it were the ultimate indicators of anything, including in health technology and healthcare services.

The technological breakthrough also has been disrupting the world of education. In the field of health we speak about Health 4.0. In the education one, we should prioritize Higher Education 4.0: Higher Education of Public Administration 4.0. This idea will ultimately revolve around the idea of encouraging the College or University to function a locomotive of change, being a future trendsetter through the excellence of research findings, technologies, theories, brilliant ideas, and development models that are desperately needed by many stakeholders. Revolution or disruptive innovation in curriculum, technology and education and learning, collaboration, research and development, and of course human resources, are the must factors.

A few years ago, Riady (2004) wrote NanoTechnology Management Style. His idea of College or Universitie in the era of nanotechnology I think is very interesting and needs to be 
addressed again, because it's still very relevant. He envisions they can achieve university excellencies with a management style that fits with the era of globalization, digitization, and futurization.

Now, we hope they may realize those hopes. Instead of being a problem, we expect them to be the solution of problems facing by the nation. According to Sri Mulyani as Minister of Finance, corruption is a serious problem for our nation. But the real role of universities in development is also as serious as problem of the corruption. We should be ashamed to hear this judgment.

\section{Creative Destruction}

Actually, disruption is not a new concept. Conceptually, it deals with innovation. In the theoretical framework of Christensen the innovation is divided into two types, namely the evolutionary and revolutionary. The evolutionary innovation does not cause disruption, while the revolutionary causes disruption.

The concept of innovation of Schwab and Christensen is revolutionary. It is not only new, but creative and destructive in the sense that it change or replace totally the old product (incumbent) and systems that support it.

In the future it is not impossible for state and government to provide public services provided digitally. Roborts have repalced the workforces. Even in this state there is a robot that can deliver mail faster. The robot is named CarriRo. With GPS technology, they is guided to the addresses in question. In Indonesia, some jobs have been taken over by technology using sensor technology, such as ATM for banking, e-toll for toll, e-ticket for parking.

Kasali warned us that disruptive innovation only has eliminated certain jobs, but not the work. Therefore, disruptive innovation presents new opportunities for businesses actors that prioritize the platform. Application of sophisticated technology and information is a necessity. The key is the development of human resources.

There are jobs that are irreplaceable by computers or automation technology, namely:

1. Mental health and substance abuse social workers.

2. Choreographers.

3. Physicians-surgeons.

4. Psychologists.

5. Human resources managers. 
6. Computer systems

7. Anthropologists-archaeologists.

8. Marine engineers-naval architectures.

9. Sales managers.

10. Chief executives. ${ }^{8}$

Brodjonegoro in the same article revealed that the skills that skill relevant to the era of RI 4.0 are as follows:

1. Social skills.

2. Engineering knowledge.

3. Problem analysis.

4. Design/development of solutions.

5. Investigation.

6. Modern tool usage.

7. The engineer and society.

8. Environment and sustainability.

9. Ethics.

10. Individual and teamwork.

11. Communication.

12. Project management and finance.

13. Lifelong learning.

Seven of them are soft skills, while the rest are hard skills.

14. Doctors (physicians) and surgeon for their ability to handle unique and complex patients.

WEF (2015) predicts 10 top skills needed in 2020 and 2030. Although the era is very technological, but the skills needed are, for the most part, soft skills with highly critical thinking. 
Table 2.

Top Ten Skills in 2020 and 2030

\begin{tabular}{|l|l|}
\hline \multicolumn{1}{|c|}{ Top Ten Skills 2020} & \multicolumn{1}{c|}{ Top Ten Skills 2030} \\
\hline- Complex problem solving. & - Complex problem solving. \\
$-\quad$ Critical thinking. & - Coordinating with others. \\
$-\quad$ Creativity. & - People management. \\
$-\quad$ People management. & - Critical thinking. \\
$-\quad$ Coordinating with others. & - Negotiation. \\
$-\quad$ Emotional intelligence. & - Quality control. \\
$-\quad$ Judgment and decision making & - Service orientation. \\
$-\quad$ Service orientation. & - Judgment and decision making. \\
$-\quad$ Negotiation. & - Active learning. \\
$-\quad$ Cognitive flexibility. & - Creativity. \\
&
\end{tabular}

Source: WET (2015)

All educational institutions, especially higher education, must reorient their platforms (vision, curriculum, learning and social service, research and development) in order to equip their students with highly critical thinking. Such high-level thinking-based expertise is needed in the ERA of RI 4.0.

\section{Closing Remarks: Disruptive Governance Paradigm}

The description above discuss wide story about some future trends, about the global forecast, about the future organization, about megachanges 2050, about future employees 2050, and about vision 2050. And, as mentioned above, the public administration as a science needs a new DNA to adapt to theses trends.

The concept of disruption in disruptive governance paradigm does not connotate deconstructing old governance or government but adds a number of characteristics that correspond to its era. The governance and government actions remain and are even stronger and wiser, but the platforms are different, both:

1. Leadership - disruptive leadership.

2. Management - disruptive management.

3. Organization - disruptive organization (ExO).

4. Employees (ASN) - disruptive employees. 
5. Skill - disruptive skills.

and:

6. Way of thinking or mindset - disruptive mindset.

7. Work culture -- disruptive culture.

\section{Picture 1}

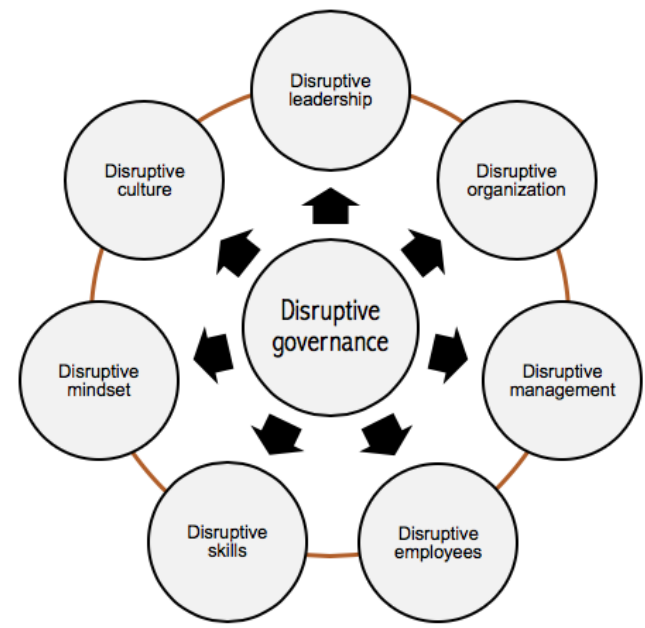

Let's we try exploring these characteristics one by one with some important notes: [1] we are in line with Kettl's concept of transformation, but we have to reject his ideological background; [2] the scope of state, government and public sector responsibilities will be as large as the region and population, as well as its dynamics; [3] which has consequences for the scope of its activities that must be all-embracing; [4] although in its implementation it cannot be done alone; [5] state activism became a necessity, which then insisted its presence in trengginas, agile, disruptive, adaptive, and humane manner (pro-poor, prosocial equity, and pro-sustainable development) through the formulation and implementation of public policy, development programs, public services and community empowerment; and [6] the necessity to present in such a noble presence gathered all the characters, images and core values of all the paradigms that preceded it.

We start from the global forecasts compiled by Randers that we relate them with the other thoughts. He mentioned that the state engagement and stronger government as two of the trends he predicted until 2052. From the point of view of public administration, the presence of a stronger state and wiser and government will determine other tendencies. Two tendencies determine 36 other ones. 
Randers began with a statement that the next 40 years of the world will experience resource scarcity, environmental crises, while humans want to continue to meet their needs. The solution he offer is we must have a lot of funds - for investment -- needed to address scarcity and environmental crises, as well as meet human needs.

The question is, where will the money come from? This question is the starting point of his prediction that the state would get more involved with more quality engagement or involvement.

Although the funds and other resources needed for the investment can be accumulated with private and social sectors, it requires a skill of partnership or collaboration for state or government. The state and government engagement must be in the corridors of state activism. It requires a disruptive government to build partnerships with any party, which is able to improve the living standards of citizens without hegemonizing the state and government by the other sectors.

Partnership or collaboration like this need new bold platform and require disruptive leadership and skills within the framework of stronger government, so that partnerships are not structured to appropriate state sovereignty (silent takeover) and hinder the development of grass-roots' economy. A stronger and wiser government is important for law enforcement, when for example, private and other sectors involved in collaborations violate the rules of the partnership or collaboration, especially in maintaining the sustainable environment and the citizens welfare.

Thus, more intensive state engagement and stronger government are an important component in disruptive government, which may only be resulted from of disruptive leadership and skills, namely the altrocentric model (Vielmetter and Sell) or Swarm Leadership model (Kelly). Most of the skills in these models are soft skills, the skills that are very relevant for the era of RI 4.0. Stronger government in disruptive government paradigm should have all these characteristics: disruptive employees with disruptive skills and work ethos supported by disruptive management.

Second, population and workforces will peak earlier. It's also a trend that will happen in the future. The population is growing. Labor forces is increasingly hoarding its numbers. They will be fighting for getting more decent jobs. Competition will be inevitable with the risk 
of some not getting a share or out of competition. The conditions can lead to inequality and social inequality.

Innovation as solution is like a knife. We can use it to peel food, but it can also injure

a person. Disruptive innovation has leverage effects to overcome poverty, but its potential to bring destitution and poverty to certain segments of the population is also no less great.

In facing these situations, the state is not just hand-on and the government is not just stronger. They should be wiser. In this era we need a government who is not only strong, clean, professional, neutral, and independent, but wiser and good. There are additional demands for them to be better or wiser in the sense of they is pro-poor, siding with disadvantaged groups having limited access to public services and development program.

Sometimes certain social groups in society have to face development violence (Mowforth, 2014): marginalization, impoverishment, discrimination, and socioeconomic injustice. Strong and good government equipped by disruptive governance is expected to implement the affirmative actions or policies for overcoming social problems facing by these groups. This science should benefit as much as possible from social justice theory (Rawls, 2001 and Sen, 1997) so that this science can focus not only on the 3Es, but also on social justice through distributive justice policies, procedural and affirmative policies.

Distributive justice, procedural and affirmative policies is exactly the same as slipping handyplast on wounds on the body. It was needed only at the time of the injury. So, it only short-term. The state and governments in an era of disruptive governance also need longterm solutions that do not create dependency. Helping people to help themselves. It's the main value of the decentering governance paradigm.

Community empowerment is a theoretical foothold for disruptive conceptual platforms to replace the No! to Life Development Paradigm, which empirically led to environmental crises, social inequality, neglect of people's human rights, and the life rights of Indigenous people. This concept carries a new conceptual platform, namely Yes! to Life

\section{Development Paradigm.}

On another case. Katadata.id (2019) reports that the number of internet user in Indonesia as of 2018 has reached about 160 million more, while the habit of surfing in social media with smartphones ranks third in the world. This means that quantitatively the nation 
can already be involved in digitizing the embodiment of democracy values in every form of transaction (social, economic, political, and cultural), especially in political transactions, such as general elections, done by e-voting (Reddick et al., 2012).

Disruptive platform also have consequences on the assessment of the theme of decentralization and multi-layer governance. Collaboration, partnership, synergy, comanagement, or networking skills are the skills of the future that must be transformed into curriculum and leaerning processes of this science.

The disruptive governance paradigm with its seven disruptions rests on a trim-tab. There are two types of trim-tab. The first is put forward by Covey, while the second refers to Christensen's view. In Covey's version, a trim-tab is the small rudder that turns the big rudder. It turns the entireship. Something small, but decisive overall. Trim-tabers are employees who have disruptive skills, leadership, and disruptive work ethos within an organization. Their number is small, but it is very decisive in determining the public sector organizational excellence.The innovation needed by the dynamic governance should be built on the basis of these characteristics.

According to Christensen, innovation in disruptive governance paradigm nedes different innovations, which are not just new things. It requires conceptual and praxis different platforms. According to Kasali (2017), innovation is just doing and making something new, but dirsuption is doing all things differently, so the others will be obsolete.

Singapore made disruptive innovations. This case inspires benchmarking for the formation and development of disruptive governance and at the same time inspires the design of disruptive governance paradigm. Neo and Chen have an interesting story about this nation.

“Many observers attribute Singapore's success to the strength of its political leadership. But there is an entire administrative body working quietly behind the scenes to create, develop, review and translate policies from perception to paper to practice."

The disruptive innovation -- a trim-tab of the second type --in public service made the nation into the top 10 in the business convenience rankings and the highest ranking in the global achievement. Take a look at what they think about Singapore,

“Our study of Singapore's government institutions highlights how a foundation of cultural values and beliefs can work synergistically with strong organizational 
capabilities to create a dynamic governance system that enables continuous change. Institutional culture can support or hinder, facilitate or impede dynamism in policymaking and implementation. Institutional culture involves how a nation perceives its position in the world, how it articulates its purpose, and how it evolves the values, beliefs and principles to guide its decision-making and policy choices. In addition, strong organizational capabilities are needed to consider thoroughly major policy issues and take effective action."

That is what I called doing things differently. Here's a new disruptive platform. Not just to create something new, but also doing things with a new value and institutions. These then formed a system of thinking and culture, new conceptual and praxis platform. On these foundations the principles of managing a nation were built. Then, everything formed the living culture, namely cultures, values, beliefs, and principles which function in:

1. Catalyzing the new ideas to be realized.

2. Confronting the problems to be solved.

3. Constrainting disturbances, challenges and adversties to be opportonities.

Neo and Chen also suggested, “... there is an entire administrative body working quietly behind the scenes to create, develop, review and translate policies from perception to paper to practice." They also said, "... there is an entire administrative body working quietly behind the scenes to create, develop, review and translate policies from perception to paper to practice." The formula is simple: Change = Culture plus Capability (3Cs). Here's an important part underlying what they've achieved so far.

\section{References}

Acemoglu, D. and J. A. Robinson. 2012. Why Nations Fail: The Origins of Power, Prosperity, And Poverty. Profile Books.

Bell, T.W. 2017. Your Next Government?: From the Nation State to Stateless Nations. Cambridge University Press.

Bunasim, A.S. 2020. Tracing the Public Administration 4.0. Bildung.

Caiden, G.E. 1991. What Really is Public Maladministration? Indian Journal of Public Administration, 37(1), pp.1-16. 
Canton, J. 2006. The Extreme Future: The Top Trends That Will Reshape the World in the Next 20 Years. E.P. Dutton, Penguin Random House.

Christensen, C. and M. Raynor. 2013. The Innovator's Solution: Creating And Sustaining Successful Growth. Harvard Business Review Press.

Christensen, C.M., ME. Raynor and R. McDonald. 2015. What Is Disruptive Innovation? Harvard Business Review, 93(12), pp.44-53.

Christensen, C. M, E. Ejomo and K. Dillon. 2019.The Paradox Poverty: How Innovation Can Lift Nations out of Poverty. Harper Business.

Covey, S. R. 2013. $8^{\text {th }}$ Habits: From Effectiveness to Greatness. Free Press.

Denhardt, J. V. and R.B. Denhardt. 2015. The New Public Service: Serving, Not Steering. $4^{\text {th }}$ Edition. Routledge.

de Vries, M.S. 2016. Understanding Public Administration. Macmillan International Higher Education.

Drucker, P.F. 1980. The Deadly Sins in Public Administration. Public Administration Review, 40 (2), pp.103-106.

Dunsire, A. 1973. Administration: The Word and The Science. Martin Robertson.

Durant, R.F. 2014. Why Public Service Matters: Public Managers, Public Policy, and Democracy. Palgrave MacMillan.

Dweck, C. S. 2017. Mindset: How You Can Fulfil Your Potentials. Constable and Robinson Ltd.

Farazmand, A. and J. Pinkowski. (editors). 2006. Handbook of Globalization, Governance, and Public Administration. CRC Press.

Farazmand, A., 2009. Building Administrative Capacity for the Age of Rapid Globalization: A Modest Prescription for The Twenty-First Century. Public Administration Review, 69(6), pp.1007-1020.

Frederickson, H.G. 1990. Public Administration and Social Equity. Public Administration Review, 50(2), pp.228-37.

Fukuyama, F. 1999. The Great Disruption: Human Nature and The Reconstitution of Social Order. Profile Books.

----- 2004. State-Building: Governance and World Order in the $21^{\text {st }}$ Century. Cornell University Press. 
Garafalo, C. and D. Geuras. 2006. Common Ground, Common Future: Moral Agency in Public Administration, Professions, and Citizenship. CRC Press.

Gerstner, Jr., L.V. 2002. Who Says Elephants Can't Dance? Leading a Great Enterprise Through Dramatic Change. Perfect Bound.

Habermas, J. 1971. Knowledge and Human Interests. Beacon.

-----. 2007. Moral Consciousness and Communicative Action, Polite Press.

Hanore, C. 2004. In Praise of Slowness: Challenging the Cult of Speed. HarperCollins Publishers.

Henry, N. 2018. Public Administration and Public Affairs. 13 ${ }^{\text {th }}$ Edition. Routledge.

Hertz, N. 2003. The Silent Takeover: Global Capitalism and the Death of Democracy. The Free Press.

Hughes, O.E. 2019. Public Management and Administration: An introduction. $5^{\text {th }}$ Edition. Macmillan International Higher Education.

Ife, J. and F. Tesoriero (2006). Community Development: Community-based Alternatives in An Age of Globalization. $3^{\text {rd }}$ edition. Person Education Australia.

Ismail, S., M. S. Malone and Y. van Geest. 2014. Exponential Organizations Why New Organizations are Ten Times Better, Faster, and Cheaper than Yours. Diversion Books.

Johnson, N.J. and J.H. Svara. (editors). 2011. Justice for All: Promoting Social Equity in Public Administration M.E. Sharpe.

Kakutani, M. 2018. The Death of Truth: Notes on Falsehood in the Age of Trump. Tim Duggan Books.

Kasali, R. 2017. Disruption: Tak Ada Yang Bisa Diubah Sebelum Dihadapi, Motivasi Saja Tidak Cukup. Gramedia.

----- 2018. Agility: Bukan Singa Yang Mengembik. Gramedia Pustaka Utama.

Kelly, R. 2019. Constructing Leadership 4.0: Swarm Leadership and the Fourth Industrial Revolution, Palgrave McMillan.

Kettl, D.F. and H.B. Milward. (editors). 1996. The State of Public Management. JHU Press.

----. 2008. The Next Government of the United States: Why Our Institutions Fail Us And How to Fix Them. WW Norton \& Company.

-----. 2013. System under stress: Homeland security and American politics. Sage. 
-----. 2015. Governing in an Age of Transformation. In Perry, J.L and R.K. Christensen. 2015. Handbook of Public Administration. 3rd Edition. Jossey Bass.

Kok, J. and S. C. van den Heuvel. (editors.). 2019. Leading in a VUCA World Integrating Leadership, Discernment and Spirituality. Springer.

Korten, D. 2015. When Corporations Rule the World. $3^{\text {rd }}$ Edition. Berrett-Koehler Publishers. Lane, J.E.. 2000. The Public Sector: Concepts, Models and Approaches. Sage.

Lathrop, D. and L. Ruma. 2010. Open Government: Collaboration, Transparency, and Participation in Practice. O'Reilly Media, Inc.

Link, A.L. and J. R. Link. 2009. Government as Entrepreneur. Oxford University Press.

Lynn Jr, L.E. 2006. Public management: Old and New. Routledge.

Marini, F. 2000. Public Administration. In J.M. Shafritz. 2000. Defining Public Administration: Selections from the International Encyclopaedia Public Policy and Administration. Westview Press.

McKinsey and Company. 2017. How Digital Innovation Transforming Agriculture: Lesson from India. McKinsey and Company.

McLaughlin, K., S. P. Orborne, and E. Ferlie. (editors). 2002. New Public Management: Current Trends and Future Prospects. Routledge.

Ojo, A. and J. Millard. (editors). 2017. Government 3.0 - Next Generation Government Technology Infrastructure and Services: Roadmaps, Enabling Technologies and Challenges. Springer International Publishing.

O'Leary, R., D. M. Van Slyke and S. K. Kim. (editors), 2010. The Future of Public Administration Around the World: The Minnowbrook Perspective. Georgetown University Press.

Osborne, D. and T. Gaebler (1993). Reinventing Government: How the Entrepreneurship Spirit is Transforming the Public Sector. Plume Book.

Ostrom, V. 2008. The Intellectual Crisis of American Public Administration. $3^{\text {rd }}$ edition. University of Alabama Press.

Penprase, B.E., 2018. The Fourth Industrial Revolution and Higher Education. Higher Education in The Era of The Fourth Industrial Revolution, p.207.

Perry, J. and R. K. Christensen. (editors). 2015. Handbook of Public Administration. $3^{\text {rd }}$ Edition. Jossey Bass. 
Piliang, Y. A. 2004. Postrealitas: Realitas Kebudayaan dalam Era Postmetafisika, Jalasutra. Rainey, H.G. 2019. Understanding and Managing Public Organizations. John Wiley \& Sons. Randers, J. 2012. 2052: A Global Forecast for the Next Forty Years. Chelsea Green Publishing. Rawls, J. 1999. A Theory of Justice. Revised Edition. The Belknap Press of Harvard University Press Cambridge.

-----. 2001. Justice as Fairness: A Restatement. The Belknap Press of Harvard University Press Cambridge.

Reddick, C. G. and S. K. Aikins. (editors). 2012. Web 2.0 Technologies and Democratic Governance: Political, Policy and Management Implications. Springer.

Riady, M. 2004. NanoTeknology Management Style. UI Press.

Scharmer, O. and K. Kaufer. 2013. Leading from the Emerging Future: From Ego-System to Eco-System Economies. Berrett-Koehler Publishers.

Schwab, K. 2018. The Fourth Industrial Revolution. Crown Business.

Schwab, K. and N. Davis. 2018. Shaping the Future of The Fourth Industrial Revolution. Currency.

Sen, A. 1997. The Idea of Justice. The Belknap Press of Harvard University Press Cambridge. Senge, PM., Smith, N. Krusschwitz, J.Laur and S. Schley. 2008. The Necessary Revolution: How Individuals and Organisations are Working Together to Create a Sustainable World. Nicholas Brealey Publishing, Doubleday.

Shafritz, J.M., E.W. Russell, C. P. Borick, and A. C. Hyde. 2017. Introducing public administration. Routledge.

Schneider, H. 2017. Creative Destruction and the Sharing Economy. Edward Elgar Publishing Limited.

Siong, N.B and G. Chen. 2007. Dynamic Governance: Embedding Culture, Capabilities and Change in Singapore. World Scientific Publishing Company.

Sowcik, M., C. Andenoro, M. McNutt and S. E. Murphy. (editors). 2015., Leadership 2050: Critical Challenges, Key Contexts, and Emerging Trends. Emerald Books.

Syakrani. 2019. Making Public Administration 4.0 and Greening the Public Administration. LKiS.

Tapol, E. 2019. Deep Medicine: How Artificial Intelligence Can Make Healthcare Human Again. Basic Books. 
Thuemmler, C. and C. Bai (editor). 2017. Health 4.0: How Virtualization and Big Data are Revolutionizing Healthcare. Springer.

Vielmetter, G. and Y. Sell. 2014. Leadership 2030: The Six Megatrends You Need to Understand to Lead Your Company into the Future. Hay Group Holdings, Inc.

Waldo, D. 1948. The Administrative State: A Study of The Political Theory of American Public Administration. The Ronald Press Company.

----. 1973. Foreword. In F. Marini. 1973. (editor). Toward a New Public Administration: The Minnowbrook Perspective. Chandler Publishing Company.

Willoughby, W.F. 1927. Principles of Public Administration: With Special Reference to the National and State Governments of The United States. The Johns Hopkins Press.

Wilson, W. 1887. The Study of Administration. In Political Science Quarterly, Vol. 2, No. 2 (Jun., 1887), pp. 197-222.

Yu, G. and X. Qi. 2004. Disruption Management: Framework, Models and Applications. World Scientific. 